\title{
1 \\ A City River and its Bush
}

This book aims to explain a series of resident-driven conflicts that took place along the Georges River estuary from 1945 to 1980. In colloquial language shared across Australia, any disputes are known as 'blues'. In order to understand these Georges River blues, we need to engage the social and political history of the estuary with the environmental history of the living, non-human world - the birds, fish and oysters, but particularly the riverine vegetation and the mangroves - in this time of major change. The histories of the people and the living animals, birds and plants there had always been related but they all became caught up in post-World War II Reconstruction. Until 1945, British settler development on the river had been slow, despite leaving lasting impacts. This had generated an illusion of stability that, while welcomed by many human residents who confidently assumed that this would always be the 'picnic river', was deplored by developers and speculators alike.

The war brought sudden change. It led to the push for more factories, more building and subdivision for housing to bring people to work in the factories, and more 'social' housing for the many people 'slum cleared' out of the crowded inner city. The areas along the northern side of the river rapidly became more densely populated and suburban. While the upstream areas of the estuary saw the most industrial development, the downstream reaches, where the river was far wider and the views more impressive, began to see a boom in expensive waterfront developments, although the infrastructure like piped sewerage often lagged far behind the lucrative land sales.

The more-than-human world bore heavy impacts from these changes. Many species of birds that had lived along the river were displaced by the development and reclamations of the 1950s. The mangroves remained, but 
their behaviour began to change. Mangroves had never been what would today be called a 'charismatic species'. Like me, many people found them inhospitable, full of spiders and snakes, with sticky, sucking mud and spikey vertical roots all around them. For reasons only partially understood at the time, mangroves began to expand in the quiet bays along the Georges River estuary, pushing themselves into the awareness of residents and civil authorities alike, becoming invested with intense but widely different emotions. Oysters had already been transformed from a naturally occurring delicacy to a commercial farm product, winning the support of governments as a luxury export industry, despite the heavy manual labour needed to cultivate, shuck and bottle them. Yet the emergence of more expensive waterfront developments was beginning to put a premium on unimpeded water views. Oysters were being transformed once again, from a premium industry to a polluting eyesore, leading to the stigmatisation not only of the industry but also of the people who farmed them. This meant that, in both human and more-than-human terms, the outcomes from these Georges River blues were very mixed.

This book traces the emergence of suburban resident environmental activism in Australia from 1945 to 1980 by focusing on the lower Georges River, the estuary running through southern Sydney, flanked by sandy, swampy banks and sandstone cliffs. This waterway had risen as a freshwater river in the Southern Highlands, flowing first north and then swinging towards the east near what became Liverpool before turning south at Chipping Norton. Finally, it made one more turn, bending towards the east at Voyager Point and then on into Botany Bay. A geological shift, millennia ago, tilted the coastline upwards where Botany Bay met the sea, drowning the lower reaches and allowing the salt water and the tide to penetrate far upstream. So the Georges River flows onwards, but not as freshwater. Instead, it is an estuary - saline and tidal - from Liverpool downstream until it enters Botany Bay at Towra Point (see Map 1.1). Much of the land along the river's banks is low-lying and waterlogged, with water rising on high tides and flowing out across wide areas in floods. Today those areas would be recognised as wetlands, but in the 1970s - even after the Ramsar Convention on Wetlands of International Importance Especially as Waterfowl Habitat was declared in 1971 - the term 'wetlands' was unfamiliar in Australia. Instead, these Georges River lowlands were known until at least the 1980s as 'marshes' or 'swamps' - or sometimes just 'bush'. This book follows the language used in the resident-driven environmental campaigns along the Georges River estuary from 1945 to 1980 to explore how these low-lying places were seen and valued - and, hence, why they were fought over so bitterly. 
1. A CITY RIVER AND ITS BUSH

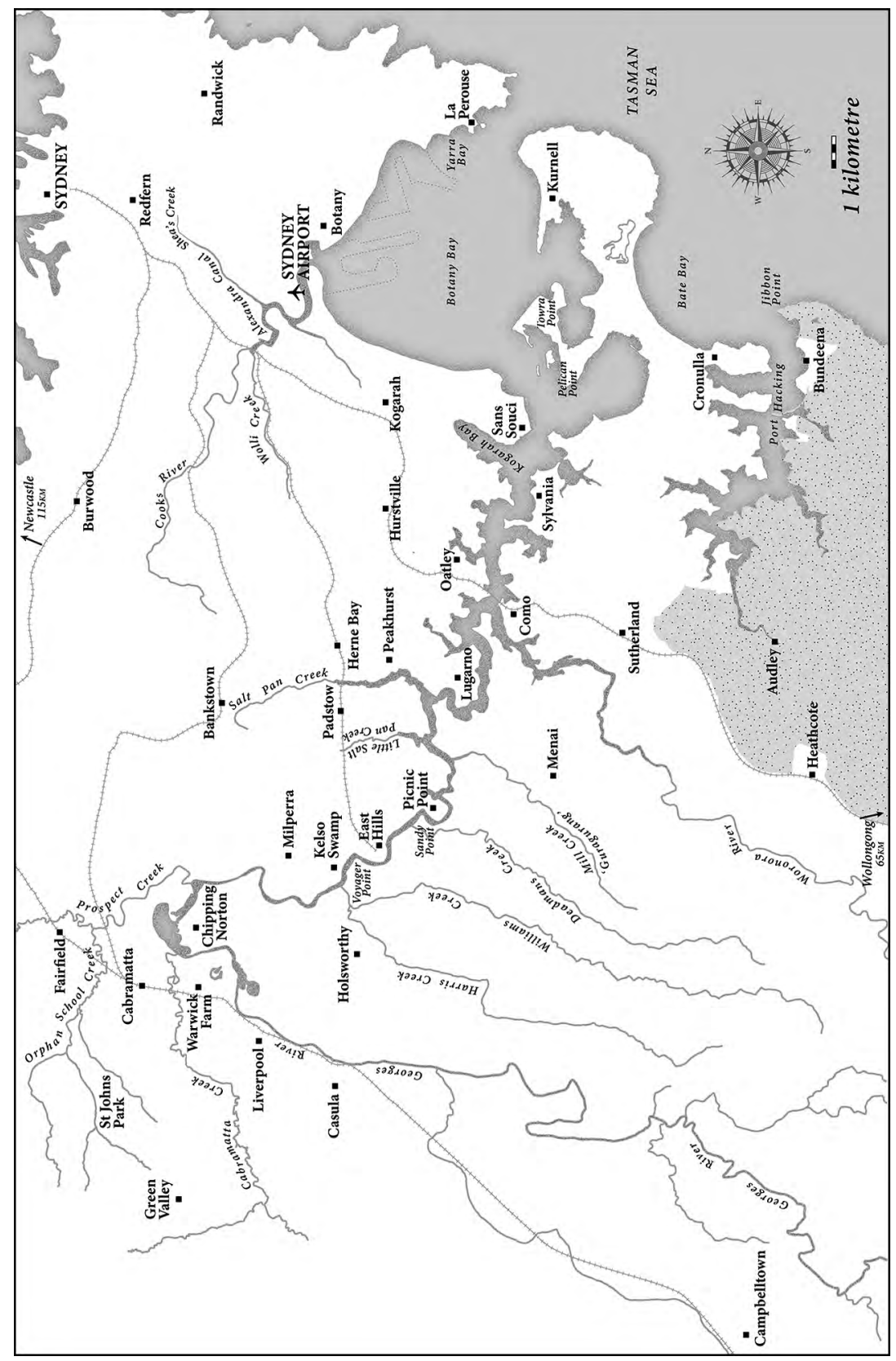

\section{Map 1.1: A city river.}

Cartography: Sharon Harrup. 
Much of this book is about the living networks of this estuary: the animal, insect and human interactions. This estuary has offered a rich habitat for salt water fish and crustaceans, and for birds, small reptiles and marsupials, with its riverbank vegetation characteristically made up by some mangroves, behind which were low-lying saltmarsh areas, often inundated at high tide, then salt-tolerant species like casuarinas (often called she-oaks but resembling pines because of their thin, grey, needle-shaped foliage ${ }^{1}$ ) and, finally, as the land rose above the salty watertable, taller shrubs and trees like melaleucas (known as paperbarks).

But rivers are still more than this. The material of the bed of a river - its soil and rock, as well as the interactions of the chemistry of soil, water and living material - contribute to the quality of water and the living networks that it sustains. The water itself is clearly essential in coastal rivers, but its flow rates and salinity have all changed over time, with interactions with surrounding environments, built or otherwise, as well as with the craft that might be employed on it by people. The shifts from canoes to rowboats and then to powerboats, for example, had significant effects not only on water quality but also on turbulence and suspended material, shaping the interactions of both human and more-than-human species. So, at times, despite our focus on living networks, geological and hydrological questions need to be considered as well.

The water and surrounding land areas identified in this book as the tidal, estuarine Georges River - from Liverpool downstream to Towra Point at the river's mouth onto Botany Bay - also relate more to human, land-based administrative divisions than to geographic definitions. Local government councils are prominent in this study because they took active roles in implementing - or resisting - the dredging and 'reclamation' projects that were the focus of most campaigns. Here the term 'upper' estuary refers to the area from Liverpool weir downstream to the Salt Pan Creek. The northern shore of this part of the river is managed by from the west - the local government areas of Liverpool, Fairfield and Bankstown municipal (and later city) councils, while the southern shore is managed by Liverpool in the west and then the Sutherland Shire. The term 'lower' estuary refers to the section from the eastern shore of Salt Pan Creek downstream to Brighton, managed on the north by Hurstville and Kogarah councils and, on the south, entirely by the Sutherland Shire.

1 Casuarina cunninghamiana or Casuarina glauca (swamp she-oak). 
This still does not exhaust the meanings that the Georges River carries. Like any waterway, this river is understood very differently for the people who live along and hail from it. While the following chapters will tell more of their stories, the Georges River has continued to hold many human meanings at the same time. For thousands of years it had been a productive river for the Dharawal, Dharug and Gandangara peoples who lived along its shores, as well as being the source of the many narratives that sustained a rich culture across the region. Despite losing many people to invasion violence and illness, Indigenous owners survived along the river, taking marriage partners from inland and continuing to live in sheltered spaces of their country along the river. ${ }^{2}$ The river land soils were not well suited to European agriculture, but there were still avenues for the river to offer productive environments for the settlers too, with small commercial ventures arising from fishing, timber and lime, along with the cultivation that could be sustained on sandy soils, like poultry, vineyards, orchards and, later, on the waters themselves, oyster farming. Such productive uses supported only a sparse settler population in the nineteenth century, although there was some increase in numbers before World War II (WWII). So the Georges River remained a 'picnic' river - a place known for its bush, fishing, duck shooting and boating; a place to go for a day trip away from the crowded city.

With WWII, however, this changed dramatically - as later chapters will trace. Noel Butlin has argued that the major impact of postwar industrialisation and migration was to fall most heavily on the Georges River estuary, leading to this 'picnic' river becoming subdivided and developed, crisscrossed with rail lines and roads, a drain for large volumes of human and industrial waste. Its landscape became recognised by all its residents as 'suburban' while its waterway became more polluted. It was here, along this damaged, suburban river, that so many battles broke out to try to save its bush and waters - and, downstream, its lucrative views. These were the Georges River blues. They had mixed social, political and environmental outcomes, and they have been ignored in conservation histories. Yet they were at least partially successful in retaining something of the meaning of the Georges River as a rich, productive and 'bush' river.

2 Goodall and Cadzow, Rivers and Resilience. 
Recognising this complex history and demography, I realised I needed to extend the frame we had used in earlier research in a number of ways if I wanted to understand what had motivated these Georges River blues the many conflicts that took place in the postwar decades to try to save a damaged river and its bush.

\section{A Longer Time Frame}

First, I needed to take a longer view chronologically. Although it concentrates on the post-WWII period, this book first sketches out the period from colonisation up to the Depression. Next it explores the period from the end of WWII, through the 1950s campaign for the Georges River National Park and its aftermath in expanding official and bureaucratic controls. It continues by considering the pressures escalating on the river and finally investigates the burst of environmental activism in the later 1960s through to 1980 .

\section{History, Colonisation, Migrancy and Culture}

Second, taking a longer time frame meant I needed to consider how these actors saw themselves in relation to invasion, colonisation and continuing interaction with Indigenous peoples. My previous work about people on the Georges River has concentrated on specific cultural groups, although each group has been heterogeneous with many complex internal differences. I have worked with and written about Indigenous peoples in Rivers and Resilience, Vietnamese Australians in Waterborne and Arabicspeaking communities in Waters of Belonging, all on the Georges River. ${ }^{3}$ While this book focuses on environmental campaigns conducted largely by residents with Anglo-Celtic settler or immigrant backgrounds, this demands inquiry into how those Anglo-Celtic residents saw themselves in relation to other communities and their relationships to the river.

3 Goodall and Cadzow, Rivers and Resilience; Cadzow, Goodall and Byrne, 'Waterborne: Vietnamese Australians'; Goodall, Byrne and Cadzow, Waters of Belonging. 


\section{A Wider Geography}

Third, I needed to take a wider geographic focus. This book looks beyond the early national park to consider the lands and waters of the estuary, with a focal area from Milperra downstream to Towra Point at the mouth of the Georges River as it enters Botany Bay. This immediately showed the significance of two places that had a powerful influence on the residents of the Georges River estuary.

One was the nearby national park, just to the south of the Georges River, which was set aside in 1879 to be the first reserved land called 'national' in Australia. It was managed by one of the same local government councils (the Sutherland Shire) that would become involved later in the Georges River National Park. The first national park was renamed the Royal National Park to honour Queen Elizabeth's visit in 1954, and it will be referred to as 'the Royal' throughout this book.

The second key place was the Cooks River to the north, which, like the Georges River, flows into Botany Bay. A small drowned valley estuary, the Cooks River lies much closer to the city of Sydney, so it suffered a heavy impact from the city's early industries. Rising near Greenacre, it flows eastwards, with important tributaries Shea's Creek, from its north, and Wolli and Muddy creeks, from the south.

Although both the Royal National Park and the Cooks River were important to Georges River residents, they carried opposite meanings. The Royal was a vision to which Georges River people strived, hoping to have the bushland along their own river acknowledged as being as important as the bushland in the national park to the south. The Cooks River was, on the other hand, a grim warning about what a river could become. While the soils along the Cooks River were far more suitable for European farming than those of the Georges, supporting early arcadian visions and attracting affluent and powerful landowners, it was also the site of the early settlement's most noxious industries. Organic waste from slaughterhouses, wool scours and tanneries polluted its waters along with the human waste that flowed from the major population expansion from the 1860 s to the 1880 s, as well as inner-city sewage, into Shea's Creek. The CSR sugar refinery at Canterbury, from 1842 to 1855, and other early heavy industries in the east of the catchment, added to the damage to the river's waters. However, because it was segmented early in its colonial history by dams at Tempe in 1832 and a weir built in 1842 
near what became Canterbury Road, the impacts were varied along the river's short length. There could still be illusions of arcadian river pastimes even while other segments of the river were being 'improved' by concrete and canalisation - as was Shea's Creek between 1886 and 1900, becoming Alexandra Canal. This book will consider the Cooks River, not in detail as Tyrrell has done, but as it was seen by Georges River residents: 'a river despoiled' - a lesson about what could befall the Georges River if it were not defended. ${ }^{4}$

The damage to the Cooks River took place throughout the whole two centuries of colonisation while, as the following chapters show, the Georges River saw much slower damage across the nineteenth century, leading to the illusion of stability that was shattered by the rapid changes of the midtwentieth century. This book focuses on responses to that sudden change along the Georges River from 1945 to 1980. It does not consider the major conflicts over Botany Bay, beginning in the 1970s but coming into full view in the 1980s as the emerging organised environmental justice movement battled with huge transnational companies against industrial and environmental damage. The blues on the Georges River had different protagonists. On one side were local people, including those living and working on land as well as those who lived along the river but worked on its waters, fishing or farming oysters. At the outset of the campaigns, these different groups of local people seldom worked together - in fact, they were often barely on speaking terms. Yet they were all confronting their own municipal authorities over directions for urban planning and sanitation in very local conditions. The battles in the Georges River estuary were not so dramatic as those later in Botany Bay but they were just as bitter and the resident groups just as tenacious. Oral histories conducted over the last 20 years and the many archival sources from the period from local organisations, newspapers and government inquiries allow an opportunity to look closely at how these widespread resident environmental action campaigns developed.

4 W. B. Malcolm, NSW Fisheries Branch, on plans for extensive bacteriological testing of the Cooks and Georges rivers and Botany Bay in 'Exhaustive Pollution Tests Soon', Bankstown Torch, 20 August 1969, 1, 3 . 


\section{What is 'Suburban' Environmentalism?}

Fourth, if I wanted to understand this activism I was hearing about in the oral histories, and reading about in the archives - as well as to explore the relationship with the Indigenous and multicultural histories I knew on the Georges River - then I needed to take a closer look at the writing on 'suburban environmentalism'. This led me to consider the way histories of cities and their environments have been addressed as well as how the histories of the Australian environmental movement have been written.

The word 'suburban' simply refers to a residential land area related to, but at some distance from, an urban area, yet it has developed denigratory meanings. While there has been a general equation of 'suburban' with middle class, the Georges River was a complex area in class terms. Certainly, all suburbs are not the same - just as not all environmentalists are the same. I needed to explore suburban environmentalism on this river by recognising its substantial working-class populations as well as the continuing presence of Indigenous peoples, the gentrifying new Anglo residents, and the incoming migrant and often non-Anglo communities. The book traces seven resident environmental campaigns on this estuarine stretch of the Georges River: one in the 1950s, one in the 1960s, then five occurring virtually simultaneously across the decade between 1967 and 1977 , with one of them stretching to 1980 . All of these campaigns had a vision of the river at their core. Each exhibited distinctive features that set it apart from the others, yet there were many shared concerns and all of them were in communication with the others, whether in friendship or conflict.

The twentieth century saw the expansion of suburbs around cities in the UK, the US and Australia. Much literature has been dismissive of suburbs, depicting their residents as embodying a conservative social order that emerged in the later nineteenth century, and focusing on private ownership of land and the privacy of spaces within fence lines. This social order - thought to be expressed in suburban architecture - assumed the dominance of men over women but also expected the control of humans over their private land-based gardens, in which natural processes were to be tamed and reordered, however they might be artfully arranged as 'wilderness'. Both literature and theatre have denigrated suburbs as barren wastelands of cultural mediocrity and environmental 
erasure. ${ }^{5}$ In Australia there has been scathing and sustained criticism of suburbanism for its alleged isolating individualism, pressure for conformity, anti-intellectualism and repression of women. ${ }^{6}$ Contributing to this narrative were the chemical and technological advances arising from WWII that were seen as conquering nature: herbicides, pesticides and the green revolution were all said to be fulfilling 'modern' human mastery over nature.

While many of these criticisms had elements of truth in them, each must be qualified to understand postwar environmental activism on the Georges River. Head and $\mathrm{Muir}^{7}$ and, most recently, Andrea Gaynor have challenged the narrative that suburban land-based gardening confirmed human dominance over the more-than-human world. Gaynor points out that attempts to garden either for food or ornamentation in suburban conditions nurtured among gardeners an embodied and everyday interaction with the natural world that often contradicted the view that human dominance was growing over nature through technological and chemical industries. Their experiences were often far more ambivalent, with many of them forced to grapple with the refusal of the natural world to bow to such controls. ${ }^{8}$ In fact, many species of animals, insects and plants demonstrated a tenacious resilience in the changing chemical environments with which they were faced, adapting and evolving in ways that led to a reassertion of their numbers and impact, much to the frustration of gardeners and the medical world.

Christopher Sellers has argued for the importance of seeing suburbs in the US as broader geographic areas rather than focusing only on privatised individual houseblocks. Sellers identifies the emergence of mid-twentiethcentury environmentalism in the interactions that suburbs allowed for residents who continued to engage with rural hinterlands as well as the interstices of the suburbs themselves, created by rivers and creeks, marshes or parks. He argues that suburban environments were valued by residents not because they set up privatised and individualised spaces that excluded

5 Sellers, Crabgrass Crucible. For denigratory approaches in Australia, see the work of Robin Boyd in architecture (e.g. The Great Australian Ugliness, 1960), Patrick White in fiction (e.g. Riders in the Chariot) and Barry Humphries (as Edna Everage) in theatre.

6 Gilbert, 'The Roots of Anti-Suburbanism in Australia'.

7 Head and Muir, Backyard. Further authors on Australian suburban environmentalism have been Benson and Howell, Taken for Granted; Davison, 'Australian Suburban Imaginaries of Nature'; Davison, 'Stuck in a Cul-De-Sac?'; Davison, 'The Trouble with Nature'; Hogan, "Nature Strip"'.

8 Gaynor, Harvest of the Suburbs; Gaynor, 'Grappling with "Nature"'. 
nature, but because they allowed residents to be more actively involved in the environments outside their own fence lines - in the broader regions beyond but still close to their suburbs. Sellers proposes that the personal, embodied interactions with the natural world that suburbs made possible stimulated the environmental activism of the 1960s and 1970s. He points out that it was the collective and shared experiences of nature that generated this activism. Instead of suburbs creating isolated individuals craving solitary experiences in pristine nature, Sellers argues that suburbs fostered a sense of collective and socially responsible environment interactions that generated - in the climate of the 1960s and 1970s a grassroots environmental movement, fuelled by direct experiences and local collective action. ${ }^{9}$ I go a step further in this book to argue that it was the slow building of alliances between groups that initially had divergent interests that eventually offered the most effective resistance to the environmental damage of reclamation.

Writing about suburban environmentalism, including that of Sellers, has seldom considered urban rivers where significant industrial workingclass populations existed, even when change was occurring. A number of important analyses have addressed the histories of Australian urban rivers, including Ian Tyrrell's valuable study of the Cooks River, discussed earlier, and those of Margaret Cook, Grace Karskens, Paul Boon and others. In all of these, however, there has more often been a focus on middle-class residents than on industrial workers or low-income groups who may have lived on these rivers. ${ }^{10}$ Recognising the mixed and changing demographics of the Georges River estuary, this book traces the form and the strategies of environmental activism on the estuary in and between both workingclass and gentrifying resident groups.

\section{The Nation and the Bush}

Another area of important reflection about environmentalism in Australia is related to urban areas in a different way. This is the concept of 'the nation', with places so often identified as symbolic of - and indeed,

9 Sellers, Crabgrass Crucible.

10 Tyrrell, River Dreams; Cook, A River with a City Problem; McLoughlin, The Middle Lane Cove River; McLoughlin, 'Mangroves and Grass Swamps'; McLoughlin, The Natural Environment of Bankstown; Rosen, Losing Ground; Rosen, Bankstown; Boon, The Hawkesbury River; Otto, Yarra; Karskens, People of the River. 
contributing to - national identity. One way in which places have been identified as emblematic of 'the nation' has been by the enshrining of an area - initially an area of land - as a 'national park'. The current meanings of the term 'national park' have been shaped by the body of ideas about conservation that developed late in the twentieth century, arising partly from the emerging science of ecology and partly from the anachronistic application of US history to Australia.

The existence and uses of the Royal National Park shaped all the Georges River environmental campaigns from the 1940s onwards. Indeed, the first campaign considered in this study aimed to create a new 'national park' on the Georges River itself. This campaign succeeded with the declaration in 1961 of a national park on some sections of the northern and southern foreshores of the Georges River from west of East Hills to east of Salt Pan Creek. The expectations of the campaigners for this Georges River national park was that it would include 'natural bush', which had become firmly established in the early twentieth century as being vegetation native to Australia, symbolising its unique qualities and its independence (at least in popular imaginations) from British colonial founders. ${ }^{11}$ Although this national park was short-lived - being demoted in 1967 to a 'State Recreation Park' - the brief existence of the park as 'national' had done two important things. First, it had brought three councils into close collaboration on environmental matters: Sutherland, Hurstville and Bankstown. Second, it left lasting memories among the residents all along the river about the types of protections to which they could aspire as well as the types of betrayals against which they had to guard.

The concept of 'the bush' was central to this vision. The Royal National Park was deliberately a reservation not over cultivated gardens but over 'native bush', the land and waterscapes being regarded, even in 1879 , as offering not only healthy recreation but also immersion in unique and valuable environments. The early British disparagement of Australian landscapes had been inverted among Australians by the late nineteenth century, when the 'bush' was coming to symbolise not only Australia's unique environments but also its difference from its coloniser, Britain. At the same time, the term 'the bush' was used to refer to harsher areas remote from the coastal cities where unemployed workers during the 1890 s depression travelled in search of work. More positive meanings re-emerged - in popular imagination if not in legal fact - as the colonies

11 See Chapter 4, this volume, for a discussion of the campaign. 
became a 'nation' with Federation in 1901. Floral emblems were imbued too with the emotional impact of World War I, which led to so many Australian deaths and created new myths about the unique character of Australian soldiers, said to have been created in encounters with 'the bush'. At the same time, the endearing depictions of native Australian vegetation in the children's books of May Gibbs - particularly the gumnut babies, Snugglepot and Cuddlepie, with their friends and enemies created generations of affectionate commitments to the, by now manylayered, idea of 'the bush'. ${ }^{12}$ It was this concept of 'the bush' on which residents of the Georges River were basing their campaign for a park that was 'national'.

Melissa Harper has demonstrated that recreation - rather than biological conservation - was the intended use of the early Australian national parks. Recreation was certainly a concern of the lead campaigners for the Georges River National Park, but they were insisting that this should be in a landscape that included 'bush'. ${ }^{13}$ The early US 'national parks' at Yellowstone (1872) and Yosemite (1890) were very different from the national park set aside in the Sutherland area by the New South Wales Government in 1879, renamed the 'Royal National Park' after Queen Elizabeth's visit in $1954 .{ }^{14}$ The US national parks were protected with the future in mind because their landscapes were considered awe-inspiring and their living species were considered pristine. Conversely, the Royal National Park was set aside in 1879 to provide recreation within an environment of distinctly 'native bush' for the nearby inhabitants of Sydney whose urban life was believed to need supplementing with fresh air and opportunities for healthy recreation within what was regarded as a 'natural' environment. It was these living, neighbouring people who were considered to be 'the nation' rather than either the 'future' or the moneyed elite who were the only group who could afford to travel to the remote US parks. The Georges River campaigners were insisting that it was workingclass and local communities that were 'the nation' for whom the national park - land and water - was to offer recreation, rather than to those from further away, and certainly not for elites. ${ }^{15}$

12 Although she did no service to banksias, on which, to this day, I look with completely undeserved mistrust.

13 Harper, 'The Battle for the Bush'; Harper, The Ways of the Bushwalker.

14 Harper and White, 'How National Were the First National Parks'. This park will be termed the Royal National Park throughout this piece to distinguish it from the Georges River National Park (1961-67).

15 Goodall and Cadzow, 'The People's National Park'. 
Much of Harper's work is consistent with Seller's recognition of the important role of informal social interactions in the activities that were important in the natural environment. Her 2017 review of the literature on what she calls 'bush-based recreation' identifies the sociality of picnics as a core element in the goals for national park uses in the nineteenth and early twentieth centuries. Cadzow has traced the gendered dimensions of bush-based exploration within landscapes regarded as uniquely Australian, identifying the entanglements of gender both in attitudes to environments and in the social and power relationships of these explorations entanglements that continue to emerge in the informal social interactions of picnics and river-based events. ${ }^{16}$ Gender was an important issue in the postwar decades on the Georges River, when expectations of gendered roles - from boys' recreation to activist public life - shaped all uses of river and river lands, and it emerges in the following pages in motivations to activism as well as in the forms that such activism took.

\section{Sociality or Solitude?}

I have used the term sociality throughout this book to indicate human social interactions that are desired, expected and valued. Such gregarious interactions may occur in everyday living or working contexts and often in recreational settings like picnics in parks or fishing on riverbanks. While not necessarily formally planned, such interactions are not competitive; nor are they unwelcome or intrusive. They are instead an expected and encouraged experience. ${ }^{17}$

Analyses of Australian conservation, however, invariably shift the focus away from informal and locally organised sociality when they consider the campaigns for parklands in Australia in the mid-twentieth century, concentrating instead on the campaigns for remote and wilderness conservation allowing solitude and contemplation, or on the emergence of scientific conservation advocates. ${ }^{18}$ In these studies, and in archival

\footnotetext{
16 Cadzow, 'Waltzing Matildas'.

17 A widely used term for informal social interactions in the disciplines of sociology and anthropology. See for example Strang, 'Substantial Connections'; Clark, 'Social Actions, Social Commitments'; Enfield and Levinson, The Roots of Human Sociality.

18 Harper 'The Battle for the Bush'; Harper, The Ways of the Bushwalker; Harper and White, 'How National Were the First National Parks'; Hutton and Connors, A History of the Australian Environment Movement; Mulligan and Hill, Ecological Pioneers; Robin, The Flight of the Emu; James, Cosmopolitan Conservationists; Griffiths, 'Environmental History, Australian Style'.
} 
collections such as the Dunphy Papers, the campaigns of the Georges River and their wider motivations disappear from view entirely, despite Myles Dunphy's family residence in the heart of the Georges River and only 10 metres from the Oatley Park fence at Oatley West. Yet the campaign for the first Georges River National Park (1950-61) was quite explicit in its goals for recreational access for local working-class people to the foreshores and waters of the river, on lands that included picnic areas as well as playing fields but that retained what they called 'bush' or 'native' environments. ${ }^{19}$

Tyrrell has noted the interest in informal social activities on the Cooks River through this period, alongside the interest in engineering 'improvements' that were characteristic of the Cooks River Improvement League (CRIL, from 1908 to the 1930s) and the early Cooks River Valley Association (CRVA, from the 1950s). Such an interest in informal social activity was often fostered, Tyrrell points out, by women, despite their usually subordinate roles in the campaigns of CRIL and CRVA. ${ }^{20}$ The emphasis of the CRVA turned, however, more towards 'modern environmentalism', which Tyrrell identifies with contemplation and solitude, after 1976. ${ }^{21}$

On the Georges River, this interest in picnics and informal opportunities for sociality in bushland did not disappear with the demise of the national park in 1967, when it was judged 'too small' and 'not wilderness' enough to qualify as a national park under the newly established state government National Parks and Wildlife Service. ${ }^{22}$ As will become clear in later chapters, the desire to take part in picnics and informal outdoor social events in native bushland became even more strongly expressed during the campaigns of the 1960s and 1970s than it had been in the 1950s. There may have been more women in active roles in the Georges River campaigns, particularly at Lime Kiln Bay and Poulton Park as the following chapters suggest, but they were still in a minority. Nevertheless, the men who took part in the Georges River campaigns from 1950 onwards also argued that the informal sociality of picnics could be retained alongside more formal opportunities for recreation like playing fields for competitive sports,

19 Goodall and Cadzow, 'The People's National Park'. Closer attention is paid to suburban interest in environments in Dorothy Kass's valuable study of the introduction of nature study, particularly of education about birds, in the New South Wales primary schools curriculum in 1905. See Kass, Educational Reform.

20 Tyrrell, River Dreams, 162-64.

21 Ibid., 175-81.

22 Goodall and Cadzow, 'The People’s National Park', 30. 
which seemed increasingly to be the goal of municipal councils. None of these campaigns advocated the ideal of 'nature' as a place of contemplation and solitude. It was the informal sociality offered by bushland family and community picnics, all gendered and shaped by cultural diversity - the sharing of food and informal social interactions as well as ceremonies like the celebration of birthdays, the naming of children or the performance of prayers - that allows us to see the continuities between the goals of suburban environmentalism on the Georges River and the uses of natural spaces including the river before and since suburbs came into existence.

The central point for the Georges River campaigners about all such informal, outdoor and social activities was that they were taking place in 'the bush' - which is today understood across many communities in Australia as symbolic of 'the nation' but also open to 'the people' - partly because it was so often seen as 'wasteland'. While 'the bush' had many meanings, it also had connotations of 'the wild', the uncontrolled and undisciplined - of the imagined essence of the unique continent that was embraced by its many peoples. The central attraction for those living around the Georges River was not only the water of the river but also the bush of its banks, and the elements of this fragile and intractable vegetation that could be encouraged or coaxed into gardens. The goal of the campaign to save Poulton Creek and its surroundings near Oatley Bay was to 'Keep bushland in our suburbs'.

\section{Environment and the Law}

In another departure from earlier work, this book takes a different view of the very substance of the 'environment'. Australia's legal and administrative structures make a clear distinction between dry land and land under water. Crown land and all private property above the high-water mark is dealt with by the Lands Department whereas the underwater land of the estuaries like the lower Georges River are owned by the same body that manages harbours and coastlines: the Maritime Services Board. ${ }^{23}$ In the period under discussion here, from the 1940s to 1980, the New South Wales Fisheries Branch had a role in regulating many aspects of the estuary. It managed leases for oysters, the construction of jetties and the conduct of dredging, which might affect fish and all aquatic animal

23 New South Wales Coastal Conference, Estuary Management Manual, 21. 
and vegetation species, although this power was seldom used before the 1960 s. ${ }^{24}$ Only after 1979 could council zoning affect the ways in which estuary underwater land and foreshores may be used, including in the use of dredging. ${ }^{25}$

Yet many of the people in the human societies along both sides of the river held a different view, in which the river was an integral part of the imagined environment within which they lived. They may fish in the river, swim in it, gather oysters from the shore or from racks in the water, boat on it or simply observe the river's flow. In all these cases, in company or alone, they understood the river as an intimately connected part of their environment. In ecological terms - considering biology, geology and hydrology - the river waters and the river lands were interdependent and interacting, continuously shaping and reshaping each other. While the human perception of the river may have been more limited and fixed than the ecological - in that humans, for example, expected rivers to have fixed 'beds' and so they identified floods as unusual or even unnatural nevertheless, the human view of their world, in cultural and imaginative terms, was closer to the ecological than it was to the legal.

\section{Seeing the World as More-than-Human}

Just like the river itself, the living beings in the more-than-human world all play important and active roles in this history, but history has often been written as if it were separated into human history and 'nature', where 'nature' - or living, non-human species - was little more than a backdrop to human actions.

Tracing out the stories of resident human environmental campaigns raises questions around what non-human species were fought over, what species were seen and what were unseen, what has been remembered and what forgotten. The history of these human resident campaigns on the Georges River estuary brings a number of non-human groups into view, most notably oysters and, because of their absence, the birdlife of the disappearing swamps. But it was mangroves that came to bear the most emotive and contradictory baggage arising from the conflicts between

24 Ibid., 20; New South Wales, The Fisheries and Oyster Farms Act 1935.

25 New South Wales Coastal Conference, Estuary Management Manual, 14, through the Environmental Planning and Assessment Act 1979. 
humans over environmental change. No species is isolated from others, but the ecology of mangroves - that network of interacting living beings within which mangrove species existed - was lost to view. It was mangroves alone that became the object of such emotional attention.

The possibility of writing relational environmental histories, in which the relationships between changes over time in human and non-human species are understood to be in interaction, has been explored by Emily O'Gorman and Andrea Gaynor in their paper 'More-than-Human Histories', drawing on work from across the environmental humanities. ${ }^{26}$ Georges River Blues does not achieve such a relational history, but it is written with the hope that it takes a step towards that approach. The goals and concerns of the Georges River resident campaigners were always interrelated with the changing behaviour of living mangrove species on the river, as well as the intensifying - and contesting - emotions that were being inscribed onto the plants over the time frame of this study. It is these interrelationships that the book seeks to trace. The human histories cannot be understood without seeing their interaction with the changing behaviours of mangroves as well as the changing imagined depictions of mangroves among all the contending parties.

\section{Mangroves: Emerging from the Swamp}

The concept of 'the bush' has been undifferentiated so far in this chapter, and for many people it has been a broad term. Yet mangroves have come to occupy a distinct and contested place within that broader concept of 'the bush'. The vegetation of low-lying sheltered bays and river shores is now understood to be complex, including microscopic creatures as well as a large diverse group of plants classified as 'macrophytes', meaning simply plants that are visible to the naked eye and that tolerate a fully or intermittently flooded environment. Some macrophytes are always below the waterline. In estuarine swamplands, they may be seagrasses or similar plants, while other macrophytes tolerate tidal inundation, with the whole plant or its roots fully underwater at high tide and above the water at low tide. In Botany Bay and the Georges River, the visible component of the macrophytes in the low-lying, watery areas was made up of a number

26 O'Gorman and Gaynor, 'More-than-Human Histories'; Adam, 'Mangroves and Saltmarsh Communities'. 
of small plants and taller reeds in waterlogged soil known collectively as saltmarsh, and between the water and the saltmarsh were small numbers of mangrove trees.

Mangroves were just the largest of the macrophytes in estuarine low-lying watery lands - usually closest to deep water, with much of their root system in silt where little oxygen existed. Some mangrove species draw in oxygen from buttress roots above the silt. In the temperate zone like Sydney, the dominant variety, Avicennia marina, is characterised by thin pneumatophores that rise vertically up through the silt from horizontal, submerged roots, making the mud around them look spikey and forbidding. ${ }^{27}$ The other variety is Aegiceras corniculatum, otherwise known as the river mangrove, able to thrive in less saline waters and generally smaller and with more rounded leaves than Avicennia m. ${ }^{28}$

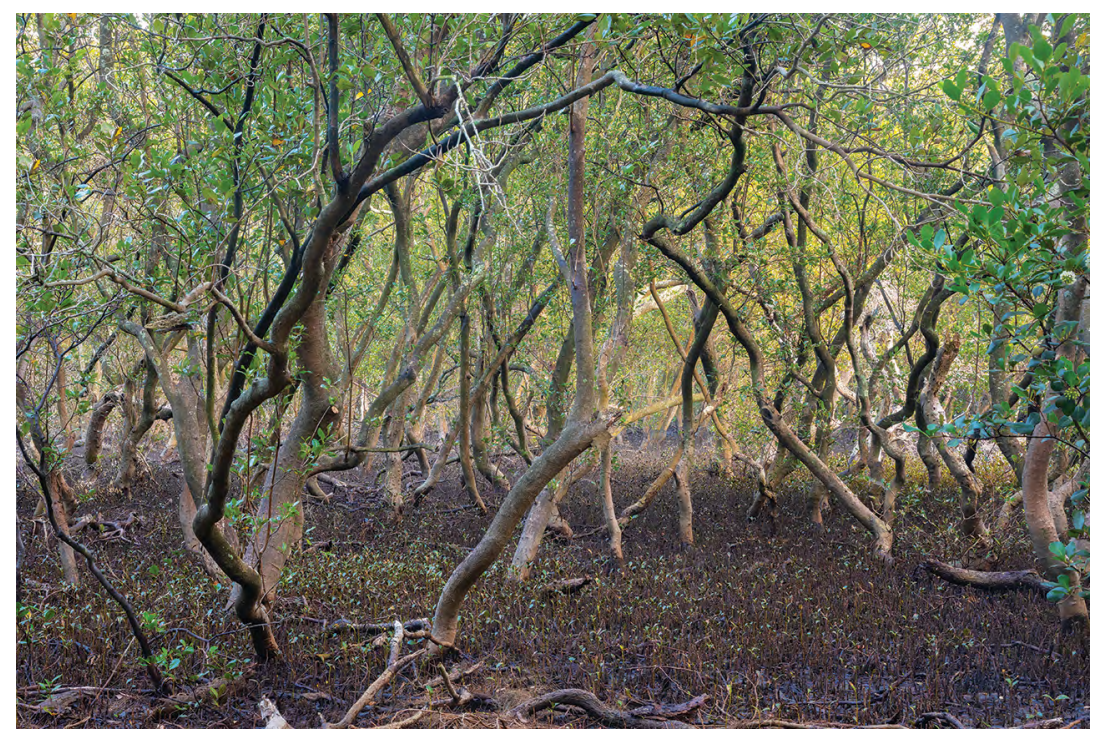

Figure 1.1: Within a Georges River mangrove stand, low tide.

This photograph suggests the eerie wildness inside a Georges River mangrove stand. Photographer: John Dowling, Illawong. 'The Tide is Out'. Courtesy of Inmagine Group.

27 Adam, 'Australian Saltmarshes in Global Context'. Adam draws on comparative data from temperate saltmarsh areas in South Africa, south-west and south-eastern Australia, New Zealand and temperate South America.

28 Ibid. 


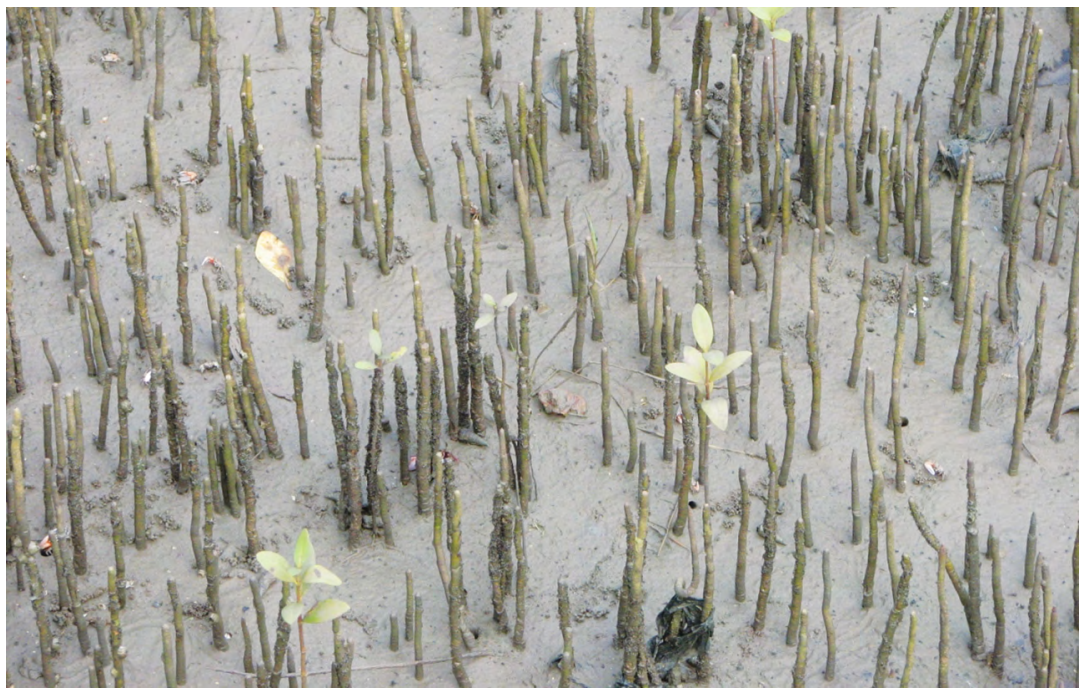

\section{Figure 1.2: Mangrove pneumatophores, the upright roots allow the plant to bring in oxygen.}

Mangroves grow in deoxygenated mud, so the pneumatophores rise vertically from underground horizontal roots, allowing the plant to access oxygen from the air. Wikipedia, Creative Commons.

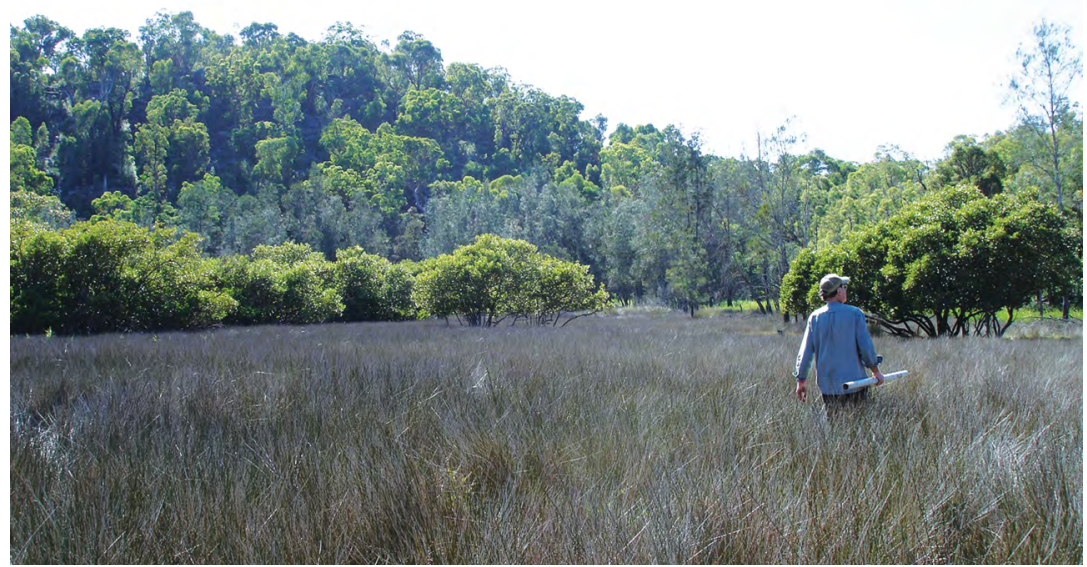

Figure 1.3: Georges River saltmarsh at Mill Creek (Guragurang), 2009.

The foreground includes the succulent Sarcocornia quinqueflora (known as samphire) and Juncus kraussii (sea rush). In the middle and rear distance are mangroves (Avicennia marina) in front of taller, salt-tolerant plants such as varieties of Melaleuca and Casuarina. Geographer Dr Robert Haworth can be seen striding across the saltmarsh on the right. This photograph was taken from the middle of the saltmarsh, looking towards the landward side. There were mangroves behind the camera, between the saltmarsh and the river. Photographer: Heather Goodall. 


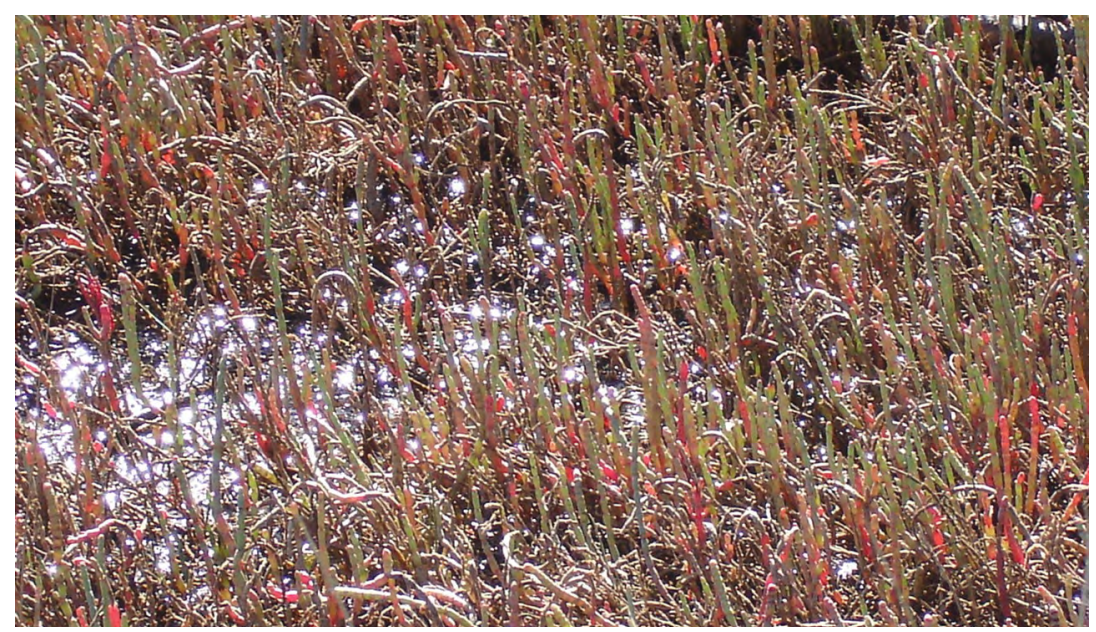

Figure 1.4: Looking downwards, showing inundated roots of saltmarsh.

Another view of saltmarsh at Guragurang (Mill Creek) in 2009, looking down through the rushes or reeds to show the inundated roots of the saltmarsh species, Sarcocornia quinqueflora. Photographer: Heather Goodall.

Temperate zone mangroves were known in earlier decades to be a favoured site for oyster spawn attachment and had generally been seen as valuable for aquatic creatures like fish, but there had not been a detailed study of the temperate mangrove stands until the 1970s, perhaps stimulated by the political activity we chart later in this book. The early research about temperate mangroves and saltmarsh had seen them in a biological succession, in which bare shore might be colonised first by saltmarsh plants that would eventually be 'succeeded' by taller salt-tolerant plants like mangroves. ${ }^{29}$ Research on saltmarsh began even later, in the 1990s. The archaeology investigating the relationship between mangroves and saltmarsh suggests that, rather than a succession, mangroves and saltmarsh were interacting and often competing species. The border between mangrove stands and saltmarsh was generally distinct, but it was not fixed, instead moving backwards and forwards as conditions changed. ${ }^{30}$

Beneath the saltmarsh, there is, most commonly, waterlogged soil, intensely saline, on which only the salt-tolerant saltmarsh species are viable.

29 Pidgeon, 'The Ecology of the Central Coastal', cited in Adam, 'Australian Saltmarshes in Global Context'. See also Adam, 'Mangroves and Saltmarsh Communities'; Rogers, Saintilan, Davies, Kelleway and Mogensen, Mangrove and Saltmarsh Threat Analysis.

30 Adam, 'Australian Saltmarshes in Global Context'; Saintilan, Rogers and Howe, 'Geomorphology and Habitat Dynamics'. 


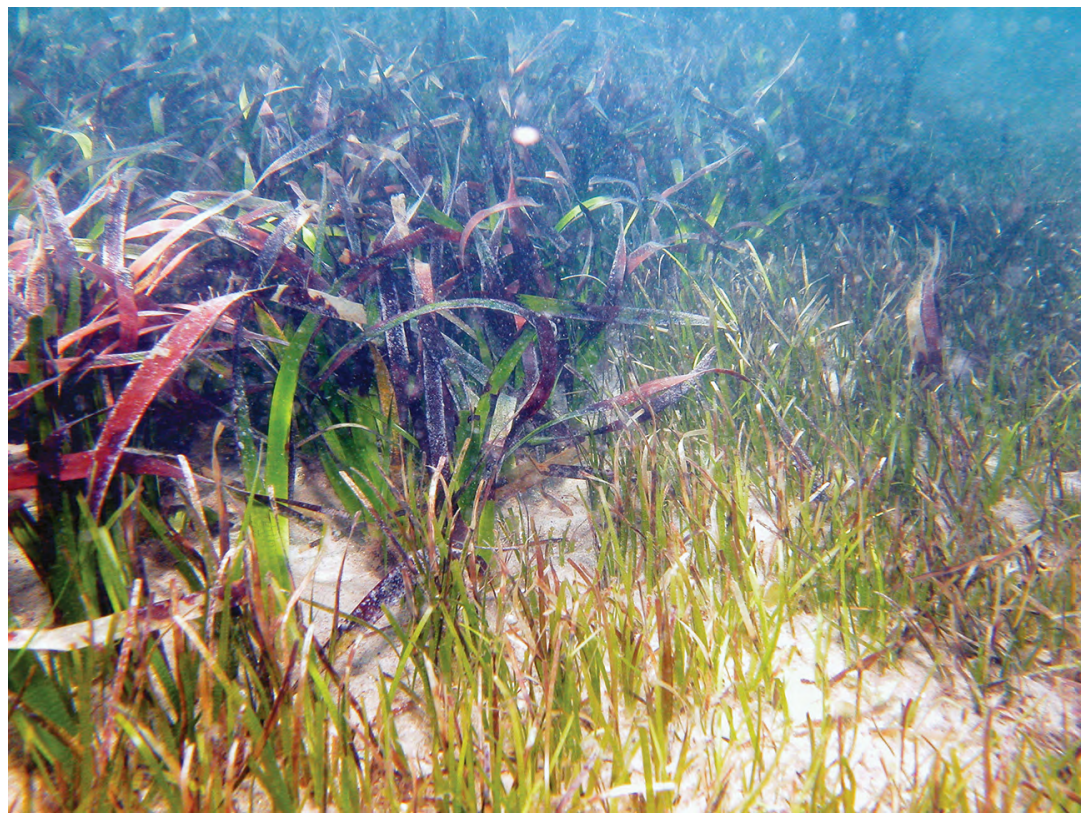

Figure 1.5: Georges River seagrasses: Zostera capricorni (foreground) and Posidonia australis (at rear).

Photograph taken at Port Stephens, New South Wales. Courtesy of photographer: Professor Tim M. Glasby.

Less well recognised, however, are the macrophytes below the surface of the waters. In the sheltered areas of Georges River estuary, where mangroves could be found along with saltmarsh before the British invasion, the plants below the waterline often included seagrasses, usually Zostera capricorni but also the broader leafed Posidonia australis (strapweed). ${ }^{31}$ Not to be confused with seaweeds (which are algae), seagrasses are land grasses that are adapted to living under the water, flowering in season and, in low nutrient conditions, far better than seaweeds at extracting resources from the waters they inhabit. Seagrasses prefer shallow, slow-moving, clear waters that give them access to sunlight to allow photosynthesis. The tiny creatures that live on seagrass leaves offer excellent food for the immature fish and crustaceans who shelter among the waving stems. The seagrasses are not themselves eaten, but their leaves die and decay, forming detritus that becomes entangled in mangrove roots, which, in its turn, offers

31 West et al., An Estuarine Inventory; West, Seagrasses; Larkum, Kendrick and Ralph, Seagrasses of Australia. 
nutrition for immature fish and crustaceans who shelter among the mangroves. The larger mangroves also offer shelter for seagrasses, slowing the flow of water and perhaps reducing waves. ${ }^{32}$

To better understand how mangroves came to change their meanings so much from the mid-twentieth century, it is helpful to return to the way they had been seen earlier. Although we know that much of the landscape of Australia was alien and disturbing for the British, it is also true that, from their first landings on the coastal estuaries of Botany Bay and Port Jackson in 1788, these settlers had found some geographies they recognised. The bays and inlets had tidal, low-lying swamps that were similar to those they knew from the coasts of south-east England and the Thames estuary. They even found plants in these estuarine swamps that seemed familiar, like the Sarcocornia quinqueflora, which was similar to the plant they knew as samphire (the Crithmum maritimum of English coasts). Once they crossed the Blue Mountains, they found inland marshes that looked like the fens of eastern England.

The mangroves seen in Botany Bay by James Cook and Joseph Banks were associated with the western areas of the bay and, while they lined the water's edge, did not appear to extend deeply on the landward side. Neither Avicennia m. nor Aegiceras c. appear on the definitive Banks and Solander list of species seen on that visit. ${ }^{33}$ John Hunter explored along the lower Georges and Cooks rivers while Cook's party was anchored in Botany Bay but, despite charting as far inland as Salt Pan Creek, he did not record extensive mangrove stands. ${ }^{34}$ In temperate zones like Sydney, mangroves consisted only of a few species. ${ }^{35}$

Tropical mangroves were different. In British India, from which many settlers came to Australia, as well as in Queensland and Papua New Guinea, there were many more species of mangroves present and they were more expansive, occupying far greater areas. Tropical mangroves were to become disturbingly familiar again to Australians during WWII, when many young men served in Papua New Guinea and other islands of the South Pacific.

32 New South Wales Department of Primary Industries, Seagrasses: Prime Facts.

33 Australian Botanic Garden, 'Banks and Solander Species List', accessed 11 October 2020, www.australianbotanicgarden.com.au/science/the-botany-of-botany-bay/plants/banks-and-solanderspecies-list.

34 Hunter, An Historical Journal; Adam, 'Mangroves and Saltmarsh Communities'.

35 Adam, 'Australian Saltmarshes in Global Context'. 


\section{Swamps and Myths}

In temperate zone areas like Sydney, at the beginning of the twentieth century and, indeed, from the beginning of British settlement, mangroves had been unremarkable - just one piece of awkward places known as 'swamps'. Although familiar, swamps carried a heavy burden of fear and prejudice that reached deeply back into the myths the settlers brought with them from Europe. Swamps were places that were seen as unnatural - waterlogged places that were not water but not land either. Such beliefs about swamps were widespread within many European cultures and had persisted through the colonisation of Australia and later waves of migration. Beliefs and fears about swamps had been reinforced by European medical teaching from its Roman origins. Swamps were believed to hold damp, rotting material within them that generated 'miasmas' - mists so fine as to be invisible but often malodorous - that were understood to circulate diseases like cholera or malaria (or fen ague) between humans. ${ }^{36}$ By the 1880s, the mosquitoes that were associated with swamps had been identified as the vectors for disease as well as irritants. ${ }^{37}$ Yet diseases were only one part of the mythology of swamps. Even more dangerous were the malevolent forces still thought to be associated with these waterlogged places, making them sources of danger and evil whether on inland plains or coastal lowlands.

This inherited burden of myths and fears about the danger of mangroves and swamps had been intensified for Australians by their WWII battle experiences in the inhospitable mangrove forests of South-East Asia. The Australian parliamentarian Henry 'Jo' Gullett remembered the 'jungle' from his WWII experience in Papua New Guinea as 'sunless, dripping, curiously silent, without birds or wild animals, yet somehow alive, watching, malignant, dangerous'. He associated it with 'a nagging insistent consciousness of one's physical weakness. ${ }^{38}$ John Cross, author of Jungle Warfare: Experiences and Encounters, praised Gullett's accuracy and added his own conflict memories of the jungle, including mangroves, as being in:

36 Halliday, 'Death and Miasma'; Nash, Inescapable Ecologies.

37 Cox, 'History of the Discovery'.

38 Gullett, Not as a Duty Only, 95. 
A state of permanent semi-twilight, gloomy even when sunshine does dapple the jungle floor with shadows, and dark in creeks and narrow valleys at noon. It is a state of permanent dampness, rain or sweat, of stifling, windless heat, of dirty clothes, of smelly bodies, of heavy loads, of loaded and cocked weapons, of tensed reflexes ... Such conditions of rain, mud, rottenness, stench, gloom ... are sufficient to fray the strongest nerves. But add to them the tension of the constant expectancy of death from behind the impenetrable screen of green. ${ }^{39}$

There did not need to be malevolent spiritual forces lurking among mangroves when there might be enemy soldiers hidden in every dark recess. The long-lasting psychological damage caused by the terrifying conditions of war has been identified recently as post-traumatic stress disorder, but such damage was seldom recognised in the mid-twentieth century. Yet, so many of the South-East Asian battles were fought out in impenetrable jungle conditions that mangroves were inevitably inscribed with the disturbing emotions faced by so many young Australian troops. Returning to Australia and seeing mangroves expanding in the southeastern estuaries must have offered an ominous warning of impending danger. It is impossible to investigate systematically how many people associated the expanding mangroves they saw in the Georges River with their residual wartime fears. Some hints, however, were given by advocates of mangrove removal, like the editor of the St George and Sutherland Leader who explained his distaste of mangroves (a plant he had described as an 'eyesore') after 'witnessing first-hand what damage mangroves can do in Papua New Guinea and Queensland'. ${ }^{40}$

39 Cross, Jungle Warfare, 18-20.

40 'Editorial: Why Keep an Eyesore?', Leader, 7 August 1974, 2. The editor's comment about 'witnessing harm' was in response to a letter to the editor entitled, 'Swamp Must be Preserved', Leader, 21 August 1974, 21. Chapters 7 and 11 will discuss the wartime experience of Hurstville Municipal Engineer A. H. Brewer in relation to mangroves as expressed in Hurstville Council Minutes, 6 March 1969, item 274, Local Studies Archive, Hurstville Library, Georges River Council Libraries. 
There seems to have been only very slow mangrove regrowth after some early settler use on the Georges River. It was apparently only after the 1930s that mangrove expansion began to be noticed by the people who lived along the river. Instead of simply being one part of a bigger entity - the swamp - the term 'mangrove swamp' became more common from mid-century, as will be seen in the following chapters. There was a growing implication that the mangroves caused the swamp.

Yet, even in the early days, mangroves had shared with swamps the quality of being ambiguous. They lived between land and water, obscuring the water's edge, smudging any clear distinction between dry land and river or sea. And they can live in brackish water, undrinkable and saline although sometimes mixed with fresh, but always lost irretrievably to humans to drink. They seemed twisted, misshapen and unruly. Yet, for those same reasons, they offered sanctuary and protection for humans and animals. Mangrove roots are confronting, either winding through the air or spiking up in pneumatophores, seeking oxygen above the waterlogged soil, allowing the plant to thrive. Not only do these roots bring oxygen into the plant, they also catch and hold detritus from the passing water, offering food to both the plant and the small creatures sheltering among those roots. Hydrogen sulphide (or rotten egg gas) is one of the chemical byproducts of rotting vegetation in anaerobic conditions. Yet all the odours are invariably blamed on the mangroves; the harder they work, the more rotting plant material they gather, the more garbage and filth they save from travelling downstream, the worse they stink. The less likely they are, therefore, to be embraced as a 'flagship' or 'charismatic' species.

As they expanded, the intractability of mangroves made them easier to hate but their visibility forced humans to notice them. This unavoidable presence made mangroves easier to defend than what lay around them, often unnoticed - the broader wetland. As this book will show, for those who desired to transform the bays into golf courses and playing fields, the highly visible and expanding presence of mangroves 'proved' that the bays were 'stinking, mosquito-infested swamps' - that is, 'wastelands'. For the defenders of the bays in the 1960s and 1970s, however, the presence of mangroves 'proved' that the waters could become clean and healthy again. Mangroves offered essential sources of nurture, food and protection for young fish, crabs and other species: they gave hope for the future. So, whether they were hated or defended, mangroves became the metonym - the symbol - for the whole imagined environment. 
The increasing episodes of environmental activism along the Georges River from 1945 to 1985 did not emerge coincidentally. Nor was the expansion of the mangrove stands accidental over the same years. While mangroves on temperate rivers like the Georges were never so extensive as in tropical lands, they carried the mythologies of forests in many cultures, embodying beliefs and fears, surprises, mysteries and horrors, so that their expansion troubled emotions as much as evoking rational responses. Activism and mangroves both grew in specific conditions, shaped by history, shifting environments and changing attitudes. The entanglements between them, and what is beneath the surface of each, are explored in the following pages. 
This text is taken from Georges River Blues: Swamps, Mangroves and Resident Action, 1945-1980, by Heather Goodall, published 2022, The Australian National University, Canberra, Australia.

doi.org/10.22459/GRB.2021.01 